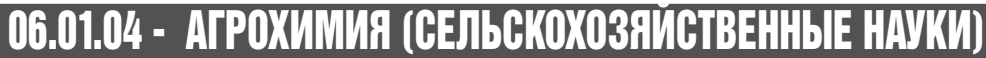

\section{ВЛИЯНИЕ МИНЕРАЛЬНЫХ УДОБРЕНИЙ И ПРЕПАРАTA NAGRO НА ПРОДУКТИВНОСТЬ КОРМОВОГО ЯЧМЕНЯ}

Исайчев Виталий Александрович, доктор сельскохозяйственных наук, профессор кафедры «Биология, химия, технология хранения и переработки продукции растениеводства»

Андреев Николай Николаевич, кандидат сельскохозяйственных наук, доцент кафедры «Биология, химия, технология хранения и переработки продукции растениеводства»

Костин Владимир Ильич, доктор сельскохозяйственных наук, профессор, заведующий кафедрой «Биология, химия, технология хранения и переработки продукции растениеводства» ФГБОУ ВО УльянОвскИЙ ГАУ

432017, г. Ульяновск, бульвар Новый Венец, 1; тел.: 8(8422) 55-95-16

e-mail: andreev919@yandex.ru

Ключевые слова: кормовой ячмень, жидкие удобрительные смеси, продуктивность, качество зерна.

Целью исследований являлось изучение эффективности комплексных макроудобрений и препарата NAGRO, а также их сочетаний при возделывании кормового ячменя в условиях лесостепи Среднего Поволжья. Применяемые фракторы положительно влияют на показатели водного баланса растений кормового ячменя. Наибольшее увеличение обеспечивает применение препарата NAGRO в сочетании с минеральными серосодержащими удобрениями. Данный показатель увеличивается на 0,4- 4,8 \% (2 часа), 0,7 - 4,4 \% (4 часа), 0,5- 3,6 \% (6 часов). Энергия прорастания при обработке семян опытным препаратом увеличилась на 0,5 - 1,6 \%, по отношению к контролю. Использование препарата NAGRO оказало положительное влияние и на лабораторную всхожесть, которая повышается в среднем на 0,4- 2,3 \%. Под действием изучаемого препарата происходит повышение силы роста за счет увеличения длины зародышевых корешков и проростков. Наибольший прирост сухого вещества в опытных вариантах наблюдался в фразу молочно-восковой спелости. Применяемые фракторы способствуют увеличению урожайности на 2,49-6,32 u/га, наибольшую прибавку к контролю обеспечивает применение NAGRO на фоне с комплексными серосодержащими минеральными удобрениями, что составляет 21,5\%. Регулятор роста NAGRO оказывают заметное влияние на все элементы структуры урожая. Самая высокая натура зерна наблюдается в варианте NAGRO на фоне минеральных серосодержащих удобрений. Прибавка от используемых фракторов составила 7,0 - 24,0 г|л, в зависимости от варианта. Под влиянием изучаемых фракторов содержание белка в зерне ячменя увеличивается с 0,07 до 1,20 \%. Суммарное количество аминокислот увеличивалось при использовании в технологии препарата NAGRO как на естественном фоне, так и на фоне минеральных удобрений. Прибавка к контролю составляет 0,22 - 3,64 мг|г.

\section{Введение}

Производство сельскохозяйственной продукции в наше время находится на таком уровне, когда рост урожайности и качества продукции возможен только при использовании последних достижений науки. Учеными разрабатываются элементы агротехнологий комплексного применения регуляторов роста, удобрений и средств защиты при выращивании сельскохозяйственных культур, обеспечивающих значительное повышение урожайности и качества растениеводческой продукции, уменьшение затрат и всех видов ресурсов, получение устойчивых урожаев даже в зоне рискованного земледелия. Регуляторы роста растений обладают полифункциональными свойствами, которые выражаются как в регуляции роста и развитии растений, так и в повышении их устойчивости к неблагоприятным погодным условиям и ко многим заболеваниям [1, 2, 3, 4,]. Однако, несмотря на то, что существует ряд примеров исключительно высокой экономической эффективности применения регуляторов роста растений, по объемам производства и использования они значительно уступают пестицидам. Не в последнюю очередь 
это связано с тем, что эффективность применения регуляторов роста зависит от эффективности всех остальных агротехнических мероприятий, включая применение удобрений и средств защиты растений. Тем не менее, низкие нормы расхода регуляторов, а также возможность управлять с их помощью процессами роста и развития растений, изменять устойчивость растений к различным внешним факторам определяют их перспективность. Регуляторы роста могут быть успешно использованы и в хозяйствах интенсивно-химизированного производства России при возделывании различных культур.

Исходя из вышеизложенного, целью исследований являлось изучение эффективности комплексных макроудобрений и препарата NAGRO, а также их сочетаний при возделывании кормового ячменя в условиях лесостепи Среднего Поволжья.

Для достижения поставленной цели были определены следующие задачи:

- выявить наиболее эффективные сочетания изучаемого препарата с комплексными минеральными удобрениями;

- установить влияние опытного препарата и минеральных удобрений на:

- параметры прорастания семян опытной культуры;

- показатели фотосинтетической активности растений ячменя;

- урожайность и качество зерна опытной культуры.

\section{Объекты и методы исследований}

Исследования проводились в 2015-2017 годах на опытном поле Ульяновского ГАУ. Опытная культура - ячмень сорта Нутанс 553. Площадь делянки -20 м², повторность опыта- четырехкратная, расположение делянок -рендомизированное. Почва опытного поля - чернозем выщелоченный среднемощный среднесуглинистый. Объектами исследований являлись: биоорганическое наноудобрение - NAGRO, а также комплексные минеральные удобрения диаммофоска N15P15K15, диаммофоска N15P15K15S10. В опыте применялась предпосевная обработка семян и в начале фазы кущения - фоновая обработка посевов исследуемым препаратом в концентрациях, рекомендованных производителем. Внесение осуществлялось одновременно с внесением гербицидов из расчетов 200л рабочего раствора на 1 га. В опыте присутствовали два фона плодородия: 1 фон - естественное плодородие, 2 фон - минеральные удобрения.

Препарат NAGRO обладает совокупностью свойств по воздействию на обработанные с/х культуры: имеет свойства удобрения; стимулирует рост растений; усиливает иммунитет растений (макси- мально и долговременно); оказывает фунгицидное и бактерицидное действия; оказывает инсектицидное действие; восстанавливает плодородие почвы; обладает исключительно высокой биологической эффективностью при применении даже в очень низких концентрациях рабочего раствора; снимает пестицидный стресс; повышает устойчивость c/х культур к резким перепадам температур, заморозкам, засухе, переувлажнению, недостатку суммы активных температур; повышает всхожесть и энергию прорастания семян, приживаемость всходов; увеличивает урожайность с/х культур от 35 до 150\%; улучшает качество c/х продукции. В состав препарата входят: B, Cu, Zn, Mn, Fe, Mo, Co, Cr, $\mathrm{N}, \mathrm{Mg}, \mathrm{P}, \mathrm{K}$, экстракт гумуса, гуминовые и фульвокислоты [5].

Анализы, учеты и наблюдения в эксперименте проводились в соответствии с общепринятыми методиками и ГОСТами. Полевые и лабораторные опыты сопровождались соответствующими наблюдениями, учетами и анализами: определение густоты стояния растений и их сохранности перед уборкой проводили путем подсчета числа растений на трех учетных площадках делянки общей площадью $1 \mathrm{M}^{2}$; в растительном материале, отобранном перед уборкой, определяли продуктивную кустистость, озерненность и продуктивность колоса, рассчитывали соотношение зерна к соломе. Определение энергии прорастания, лабораторной всхожести согласно действующей методике (ГОСТ-12038-84, ГОСТ-12041-82). Определение силы роста методом морфофизиологической оценки проростков по (ГОСТ - 12036-66). Фенологические наблюдения - в соответствии с ГОСТом 10842-64 согласно методике государственного сортоиспытания. Густоту стояния растений определяли по 2 рядкам на учетных площадках в 3-х местах делянки с длиной рядка 111 см во всех повторениях опыта. Учет фактического урожая проводили с площади всей делянки с пересчетом на 100 \%- ную чистоту и 14 \% -ную влажность (ГОСТ 2754897). Содержание белка в зерне по ГОСТ 10846-91; масса 1000 семян (ГОСТ-12042-80); натура и пленчатость зерна по ГОСТ 5060-86. Содержание аминокислот определяли на аминоанализаторе.

Во все годы исследований предшественником была озимая пшеница. Технология возделывания кормового ячменя основывалась на общепринятых в Ульяновской области агротехнических приемах.

\section{Результаты исследований}

В последние годы уделяется большое внимание разработке и применению регуляторов роста нового поколения, обладающих широким спектром физиологической активности, способных 
Таблица 1

Влияние препарата NAGRO и минеральных удобрений на показатели водного баланса растений ячменя сорта Нутанс 553, \%

\begin{tabular}{|c|c|c|c|c|c|c|c|}
\hline \multirow{2}{*}{ Вариант } & \multirow{2}{*}{$\begin{array}{c}\text { Водный } \\
\text { дефицит }\end{array}$} & \multicolumn{5}{|c|}{ Водоудерживающая способность } \\
\cline { 3 - 8 } & & 24. & 44. & 64. & 24. & 44. & 64. \\
\cline { 5 - 9 } & 14,15 & 79,6 & 66,9 & 56,0 & 75,0 & 61,4 & 53,3 \\
\hline Контроль & 13,35 & 81,4 & 68,9 & 58,0 & 75,6 & 62,8 & 56,4 \\
\hline NAGRO & 12,25 & 81,2 & 69,0 & 57,2 & 75,4 & 62,1 & 52,3 \\
\hline Контроль + NPK & 9,97 & 81,3 & 71,1 & 60,7 & 77,0 & 62,3 & 54,7 \\
\hline NAGRO + NPK & 11,65 & 78,7 & 65,6 & 56,3 & 76,5 & 63,5 & 53,8 \\
\hline Контроль + NPKS & 9,15 & 82,3 & 71,1 & 60,8 & 79,8 & 65,8 & 56,9 \\
\hline NAGRO + NPKS & & & & &
\end{tabular}

координировать, стимулировать или ингибировать различные процессы в растениях. Одним из наиболее динамичных процессов в растении является водный обмен, который находится в тесной корреляции с другими процессами жизнедеятельности растения. При умеренной транспирации и достаточном поступлении воды в растение создается благоприятный водный баланс. Прямо или косвенно вода участвует во всех жизненных процессах, протекающих в клетке. Вода является основной средой, в которой происходят все реакции обмена веществ. Активность ферментов зависит от ее количества в клетке. Она участвует в фотосинтезе, дыхании, гидролитических процессах. Для нормального функционирования растительная клетка должна быть насыщена водой. Даже небольшие изменения в содержании воды вызывают нарушение физиологических функций. Водоудерживающая способность растений является хорошим показателем водообмена растений и устойчивости их к неблагоприятным условиям внешней среды. Чем выше водоудерживающая способность растений, тем оно устойчивее. В производственных условиях часто и остро встает проблема снижения водного дефицита и увеличения водоудерживающей способности сельскохозяйственных культур $[6,7]$.

Результаты проведенных исследований показывают, что применяемые факторы положительно влияют на показатели водного баланса растений кормового ячменя (табл.1). Под действием препарата NAGRO и минеральных удобрений водный дефицит снижается на 0,8- 5,0\% в зависимости от варианта. Водоудерживающая способность ячменя в фазу выхода в трубку увеличивалась на 1,6- 2,7 \% (2 часа), 2,0- 4,2 \% (4 часа), 0,3- 4,8 \% (6 часов). Наибольшее увеличение обеспечивает применение препарата NAGRO в сочетании с минеральными серосодержащими удобрениями. Аналогичная тенденция наблюдается в фазу колошения. Данный показатель увеличивается на 0,4-
4,8\% (2 часа), 0,7-4,4\% (4 часа), 0,5- 3,6 \% (6 часов). Таким образом, использование препарата NAGRO позволяет снизить риск частых в Среднем Поволжье засух за счет оптимизации водного баланса опытной культуры, что является основой к повышению урожая и качества.

Доминирующее значение в увеличении урожайности сельскохозяйственных культур имеет качество посевного материала. Изучение посевных качеств семян имеет большое значение для понятия метаболизма. С помощью различного рода воздействий можно направленно изменять метаболизм и связанные с ним физиологические функции - рост, развитие, продуктивность и качество продукции сельскохозяйственных растений. Показателями биологической полноценности семян являются их урожайные свойства, т.е. способность сформировать высокопродуктивные растения. К числу наиболее существенных показателей, определяющих урожайные свойства семян, следует отнести: энергию прорастания, лабораторную и по-

Таблица 2

Влияние предпосевной обработки семян препаратом NAGRO на энергию прорастания и всхожесть ячменя, \% (2015-2017 гг.)

\begin{tabular}{|c|c|c|c|}
\hline Год & Показатель & Контроль & NAGRO \\
\hline \multirow{2}{*}{2015} & $\begin{array}{c}\text { Энергия } \\
\text { прорастания }\end{array}$ & $97,1 \pm 0,5$ & $98,2 \pm 0,5$ \\
\cline { 2 - 4 } 2016 & Лаб. всхожесть & $98,1 \pm 0,4$ & $98,5 \pm 0,3$ \\
\hline \multirow{2}{*}{2017} & $\begin{array}{c}\text { Энергия } \\
\text { прорастания }\end{array}$ & $91,5 \pm 0,2$ & $93,1 \pm 0,4$ \\
\cline { 2 - 4 } & Лаб. всхожесть & $94,1 \pm 0,4$ & $96,4 \pm 0,7$ \\
\cline { 2 - 4 } & $\begin{array}{c}\text { Энергия } \\
\text { прорастания }\end{array}$ & $90,4 \pm 0,6$ & $90,9 \pm 0,3$ \\
\hline \multirow{2}{*}{$\begin{array}{c}\text { Лред- } \\
\text { Лее }\end{array}$} & $\begin{array}{c}\text { Энергия } \\
\text { прорастания }\end{array}$ & $93,7 \pm 0,3$ & $94,4 \pm 0,3$ \\
\cline { 2 - 4 } & Лаб. всхожесть & 95,0 & 94,1 \\
\hline \multirow{2}{*}{ Лсхест } & 96,4 \\
\hline
\end{tabular}




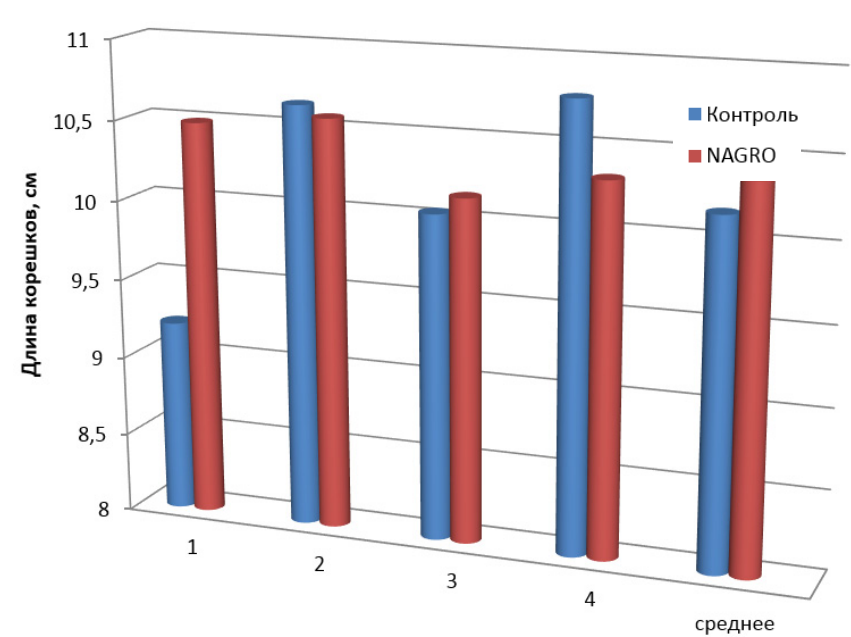

Рис. 1 - Влияние препарата NAGRO на длину зародышевых корешков ячменя, см (20152017 гг.)

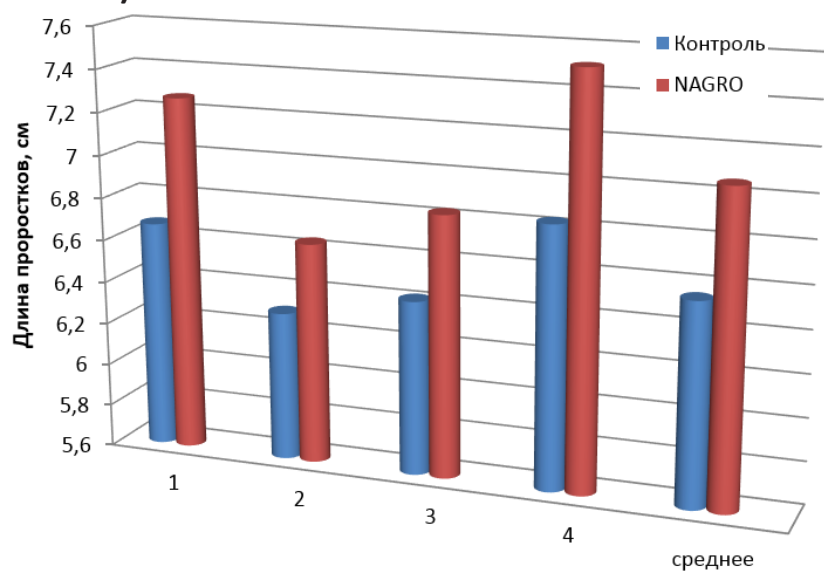

Рис. 2 - Влияние препарата NAGRO на длину зародышевых проростков ячменя, см (20152017 гr.)

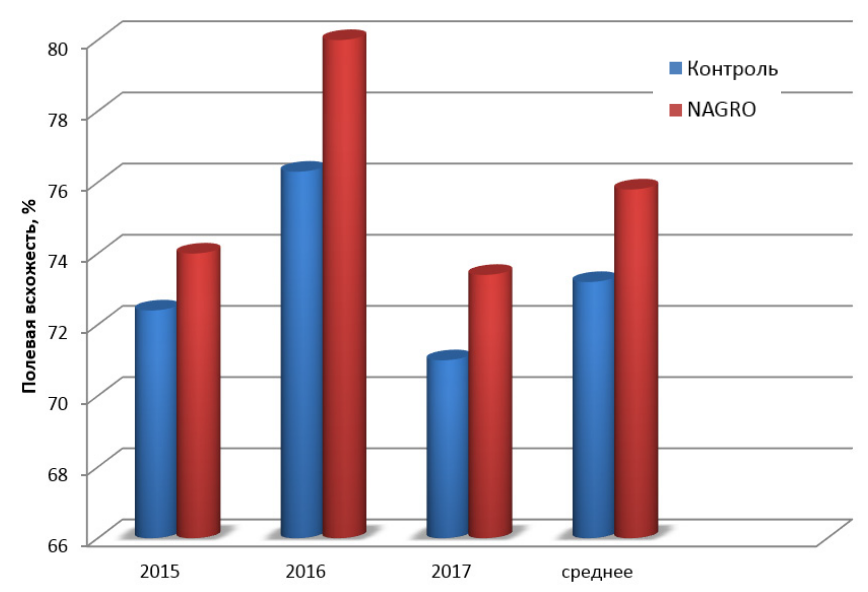

Рис. 3 - Влияние препарата NAGRO на полевую всхожесть ячменя, \% (2015-2017 гг.)

левую всхожесть и силу роста.

Влияние природно-климатических условий накладывает определенный отпечаток на реакцию растений, определяемую предпосевной обработ- кой, и не всегда можно с уверенностью сказать, какой фактор сыграл определяющую роль в получении конечного продукта. Тем более необходимо выяснение принципов действия каждого конкретного фактора, в данном случае - предпосевной обработки семян ростовыми регуляторами, особенно на начальных этапах роста и развития растения.

Как показывает практика, семена, имеющие высокую энергию прорастания, более устойчивы к неблагоприятным условиям прорастания, которые могут быть в полевых условиях, проростки таких семян быстрее растут и развиваются, меньше заболевают и повреждаются вредителями. Семена первых сроков прорастания обеспечивают лучшую выживаемость растений.

Результаты исследований показали, что под действием препарата NAGRO происходит увеличение энергии прорастания и лабораторной всхожести семян ячменя (табл. 2). Увеличение ценного показателя способствует более быстрому появлению проростков и дружных всходов. Энергия прорастания при обработке семян опытным препаратом за годы исследований увеличилась на 0,5 - 1,6 \%, по отношению к контролю. Лабораторная всхожесть повышается в среднем за 2015-2017 гг. на 0,4- 2,3 \%.

Результатами наших исследований установлено, что под действием изучаемого препарата происходит повышение силы роста за счет увеличения длины зародышевых корешков и проростков (рис. 1, 2).

Длина проростков увеличивается на 0,21 см по отношению к контролю. На длину зародышевых корешков стимулирующее действие оказывает также обработка семян препаратом NAGRO. При этом она была выше контроля на 0,51 cм.

На полевую всхожесть семян во многом воздействуют почвенно-климатические условия: температура воздуха и почвы, влажность, структура и другие характеристики почвы. Обработка семян препаратом NAGRO в наибольшей степени стимулировала прорастание семян в полевых условиях (рис. 3). В 2015 году полевая всхожесть увеличивается на 2,6 \%. В 2016 году при более благоприятных погодных условиях полевая всхожесть увеличивалась по сравнению с контрольными растениями на 3,7 \%. В 2017 году в мае стояла прохладная и дождливая погода, которая отрицательно повлияла на всхожесть. Однако использование препарата NAGRO позволило увеличить невысокую полевую всхожесть на 2,6 \% по сравнению с контролем.

Таким образом, наши исследования показывают, что под действием препарата NAGRO происходит активация ростовых процессов, способствующих улучшению посевных качеств семян, что в дальнейшем будет определять выживаемость рас- 
тений в полевых условиях, позволит избежать изреженных посевов, равно как и загущенных и, в конечном итоге, сформировать такой важный показатель, как урожайность ячменя.

Фотосинтетическая активность - один из важнейших факторов, обуславливающих продуктивность как сложную интегрированную функцию растений. Стабильность фотосинтетического аппарата обусловлена организацией всех его компонентов, в результате чего световая энергия, поглощаемая хлорофиллом, используется растением. При воздействии различных факторов (например, недостаток влаги, очень часто наблюдаемой в условиях лесостепи Поволжья) происходит снижение интенсивности фотосинтеза, транспирации, концентрации $\mathrm{CO}_{2}$ в межклетниках, содержания хлорофилла и устьичной проводимости [8].

Для изучения фотосинтетической деятельности растений в посевах необходимо оценивать те условия использования физиологически активных веществ (регуляторов роста), которые дают возможность создавать посевы, поглощающие наибольшее количество энергии фотосинтетически активной части солнечной радиации. Одним из основных показателей фотосинтетической деятельности растений, определяющих урожайность, является величина площади листьев и длительность её функционирования [9].

Установлено, что применение препарата NAGRO способствует увеличению ассимиляционной поверхности листьев ячменя. Как показали наши исследования, величина листовой поверхности во многом зависит от метеорологических условий, складывающихся в период вегетации. Наибольшие показатели ассимиляционной поверхности листьев ячменя были достигнуты в фазу колошения на вариантах с применением минеральных удобрений и регулятора роста NAGRO. При этом следует отметить положительное влияние используемых факторов не только на образование и рост листьев, но и на длительность их функционирования.

По мере улучшения водного и питательного режимов происходит более интенсивное накопление сухой биомассы растением. Считается, что накопление сухого вещества, которое является функцией процесса ассимиляции, определяет продуктивность растений. Ячмень отличается высоким темпом накопления сухого вещества надземной массы, особенно в начальные периоды роста растений.

Наши исследования выявили некоторые

Таблица 3

Влияние препарата NAGRO и минеральных удобрений на накопление сухого вещества растениями ячменя, ц/га в среднем за 2015-2017 гг.

\begin{tabular}{|c|c|c|c|c|c|}
\hline Вариант & Всходы & $\begin{array}{c}\text { Куще- } \\
\text { ние }\end{array}$ & $\begin{array}{c}\text { Выход в } \\
\text { трубку }\end{array}$ & $\begin{array}{c}\text { Коло- } \\
\text { шение }\end{array}$ & $\begin{array}{c}\text { Молочно- } \\
\text { восковая } \\
\text { спелость }\end{array}$ \\
\hline \multicolumn{5}{|c|}{2015 год } \\
\hline Контроль & 0,75 & 3,12 & 15,6 & 45,67 & 56,97 \\
\hline NAGRO & 0,80 & 3,32 & 16,48 & 48,14 & 62,09 \\
\hline Контроль + NPK & 0,83 & 3,94 & 20,83 & 60,81 & 77,07 \\
\hline NAGRO + NPK & 0,90 & 4,05 & 20,25 & 59,14 & 74,42 \\
\hline Контроль + NPKS & 0,90 & 4,10 & 22,89 & 66,88 & 80,34 \\
\hline NAGRO + NPKS & 0,84 & 4,01 & 22,34 & 67,09 & 79,42 \\
\hline \multicolumn{7}{|c|}{2016 год } \\
\hline Контроль & 0,77 & 2,80 & 15,67 & 65,24 & 86,43 \\
\hline NAGRO & 0,81 & 3,08 & 18,25 & 76,87 & 98,42 \\
\hline Контроль + NPK & 0,81 & 4,01 & 21,79 & 89,17 & 115,63 \\
\hline NAGRO + NPK & 0,92 & 4,12 & 22,50 & 90,87 & 115,99 \\
\hline Контроль + NPKS & 1,00 & 4,00 & 24,34 & 95,50 & 118,23 \\
\hline NAGRO + NPKS & 0,83 & 4,36 & 23,67 & 90,19 & 120,15 \\
\hline \multicolumn{7}{|c|}{2017 год } \\
\hline Контроль & 0,88 & 3,04 & 18,98 & 62,98 & 82,83 \\
\hline NAGRO & 0,89 & 3,79 & 21,68 & 73,99 & 97,32 \\
\hline Контроль + NPK & 0,91 & 5,29 & 29,18 & 94,83 & 123,19 \\
\hline NAGRO + NPK & 0,95 & 5,40 & 29,70 & 96,52 & 125,33 \\
\hline Контроль + NPKS & 1,09 & 4,99 & 25,89 & 95,89 & 122,55 \\
\hline NAGRO + NPKS & 0,92 & 4,65 & 25,15 & 93,00 & 117,95 \\
\hline
\end{tabular}

особенности в формировании биомассы, связанные с использованными факторами. Так, накопление биомассы существенно изменилось в связи с применением внекорневой обработки растений опытным препаратом (табл. 3).

Наибольший прирост сухого вещества в опытных вариантах наблюдался в фазу молочновосковой спелости. Содержание сухого вещества в годы исследований было различным: в 2015 году максимальное накопление сухого вещества растениями происходило при обработке препараTOM NAGRO на фоне минеральных удобрений. B среднем за вегетацию в зависимости от варианта опыта этот показатель увеличивается на 7 - 35 \% относительно контроля. В 2016 году в фазу кущения наибольшую массу имели растения с обработкой NAGRO на фоне NPKS, увеличив её на 1,56 ц/ га относительно контроля. Максимальный прирост сухого вещества наблюдается с фазы трубкования до молочно-восковой спелости аналогично во все годы исследований. В дальнейшем накопление сухого вещества происходило в основном за счет генеративных органов и достигает максимума в фазу полного налива зерна, что связано с оттоком метаболитов из листьев в репродуктивные органы ячменя. В 2017 году наибольшее накопление 
Таблица 4

Влияние препарата NAGRO и минеральных удобрений на фотосинтетический потенциал (ФП) растений ячменя, тыс.м2· дней /г, 2015-2017 гг.

\begin{tabular}{|c|c|c|c|c|c|}
\hline Вариант & 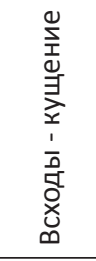 & 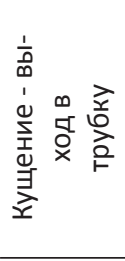 & 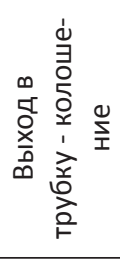 & 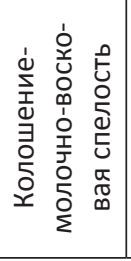 & 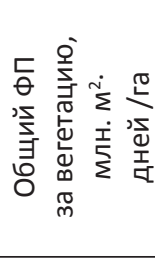 \\
\hline \multicolumn{6}{|c|}{2015 год } \\
\hline Контроль & 92,7 & 204,0 & 395,2 & 543,4 & 1,33 \\
\hline NAGRO & 117,9 & 249,7 & 453,0 & 620,3 & 1,44 \\
\hline $\begin{array}{c}\text { Контроль + } \\
\text { NPK }\end{array}$ & 117,0 & 247,5 & 447,2 & 614,6 & 1,43 \\
\hline $\begin{array}{c}\text { NAGRO + } \\
\text { NPK }\end{array}$ & 123,4 & 250,1 & 452,9 & 625,9 & 1,47 \\
\hline $\begin{array}{c}\text { Контроль + } \\
\text { NPKS }\end{array}$ & 122,5 & 257,9 & 458,0 & 628,8 & 1,48 \\
\hline $\begin{array}{c}\text { NAGRO + } \\
\text { NPKS }\end{array}$ & 121,0 & 254,0 & 453,8 & 623,2 & 1,44 \\
\hline \multicolumn{6}{|c|}{2016 год } \\
\hline Контроль & 78,8 & 175,7 & 488,2 & 549,4 & 1,28 \\
\hline NAGRO & 86,4 & 194,3 & 523,5 & 594,9 & 1,40 \\
\hline $\begin{array}{c}\text { Контроль + } \\
\text { NPK }\end{array}$ & 88,0 & 197,6 & 528,7 & 598,5 & 1,41 \\
\hline $\begin{array}{c}\text { NAGRO + } \\
\text { NPK }\end{array}$ & 90,0 & 197,9 & 553,2 & 625,1 & 1,47 \\
\hline $\begin{array}{c}\text { Контроль + } \\
\text { NPKS }\end{array}$ & 98,8 & 201,5 & 560,1 & 630,8 & 1,49 \\
\hline $\begin{array}{c}\text { NAGRO + } \\
\text { NPKS }\end{array}$ & 96,4 & 198,3 & 559,5 & 633,0 & 1,44 \\
\hline \multicolumn{6}{|c|}{2017 год } \\
\hline Контроль & 88,8 & 158,3 & 383,2 & 431,8 & 1,02 \\
\hline NAGRO & 90,2 & 173,2 & 401,5 & 447,3 & 1,14 \\
\hline $\begin{array}{c}\text { Контроль + } \\
\text { NPK }\end{array}$ & 93,5 & 174,9 & 403,3 & 452,1 & 1,13 \\
\hline $\begin{array}{c}\text { NAGRO + } \\
\text { NPK }\end{array}$ & 94,8 & 175,5 & 412,6 & 455,9 & 1,17 \\
\hline $\begin{array}{c}\text { Контроль + } \\
\text { NPKS }\end{array}$ & 95,2 & 178,8 & 432,7 & 474,4 & 1,16 \\
\hline $\begin{array}{c}\text { NAGRO + } \\
\text { NPKS }\end{array}$ & 94,4 & 179,1 & 425,5 & 470,1 & 1,10 \\
\hline
\end{tabular}

сухого вещества происходило при использовании препарата NAGRO на всех фонах плодородия. В зависимости от варианта этот показатель увеличивается в среднем на 11-30\%.

Часто возникает необходимость изучения фотосинтетической деятельности посевов сельскохозяйственных культур в зависимости от приемов возделывания в конкретной почвенно-климатической зоне. Фотосинтетический потенциал листьев (ФП) - этот показатель является обобщающим, ха- рактеризующим эффективность действия всего комплекса технологических приемов.

В связи с тем, что максимальная площадь листьев характеризует временное состояние посевов, а урожай - результат фотосинтетической деятельности посевов за весь вегетационный период, более правильно связывать его величину с интегральным показателем работы ассимиляционного аппарата - фотосинтетическим потенциалом (ФП), учитывающим не только размеры, но и длительность работы ассимилирующей поверхности. В наших опытах мы изучали влияние, оказываемое внекорневой обработкой препаратом NAGRO на фотосинтетический потенциал растений ячменя (табл. 4).

В начале периода роста растений 2015 года показатель фотосинтетического потенциала был небольшим, т.к. площадь листьев нарастала медленно. В фазу всходы-кущение наибольший ФП имел вариант NAGRO+NPK $-123,4$ тыс.м ${ }^{2}$.дней/га, на контроле 92,7 тыс.м².дн./га. Далее площадь листьев быстро начинала нарастать и в конечной фазе колошение-молочно-восковая спелость по данному варианту ФП составил 625,9 тыс.м² ·дн./ га, что выше контроля на 82,5 тыс.м² дней/га.

В 2016 году в фазу всходы - кущение фотосинтетический потенциал ниже показателей 2015 года, это связано с неблагоприятными метеорологическими условиями в данный период. В этих условиях значительное влияние на ФП оказал также препарат NAGRO, где показатели были выше контрольного в среднем на $25 \%$. Такая тенденция с ФП по данным вариантам прослеживалась до конца вегетации. Фотосинтетический потенциал за вегетацию был выше контроля на 3,7 -16,2 \%, в зависимости от варианта опыта.

В 2017 году наибольшее влияние на ФП оказало совместное применение NAGRO и комплексных минеральных серосодержащих удобрений. В фазу всходы - кущение выше контроля на 17,8 \%, кущение - выход в трубку на 26,4 \%, выход в трубку - колошение на $14,6 \%$, колошение - молочно-восковая спелость на $10,4 \%$.

Показатель чистой продуктивности фотосинтеза (ЧПФ) определяется количеством созданной органической массы зеленой поверхностью агрофитоциноза за сутки. Это очень пластичный показатель, изменяющийся под влиянием многих факторов внешней среды и обеспеченности растений минеральными веществами. ЧПФ является отражением баланса между интенсивностью фотосин- 
теза, фотодыхания и дыхания в дневное и ночное время суток.

Результаты исследований показывают, что чистая продуктивность фотосинтеза колеблется в зависимости от применяемых веществ (табл. 5). Следует отметить, что в 2015 году чистая продуктивность фотосинтеза была несколько ниже, чем в 2016 и 2017 годах.

В 2015 году чистая продуктивность фотосинтеза от обработки растений препаратом NAGRO на фоне минеральных удобрений была максимальной и увеличилась относительно контроля, составив в среднем за вегетацию 6,35 г/м² в сутки. В 2016 году в этих же вариантах прибавка ЧПФ составила 0,55 г/м² в сутки относительно контроля и достигла в среднем за вегетацию 7,72 г/м² в сутки. Максимальной продуктивности фотосинтеза ячмень достигает в период от выхода в трубку до колошения. В 2017 году в большей степени чистая продуктивность фотосинтеза также увеличивалась при использовании NAGRO на разных фонах плодородия в среднем на 14,1 \% по отношению к контролю.

Таким образом, обработка растений препаратом NAGRO способствует увеличению ассимиляционной поверхности листьев, фотосинтетического потенциала, накоплению сухого вещества и увеличению чистой продуктивности фотосинтеза опытной культуры как на фоне естественного плодородия, так и на фоне минеральных удобрений.

Урожайность сельскохозяйственных культур, в том числе ячменя, зависит от всех физиолого-биохимических процессов, протекающих в растениях в течение онтогенеза. Уровень урожайности является интегральным показателем, включающим реализацию потенциала продуктивности заложенного в геноме растения с состоянием факторов среды и современных технологических приемов, используемых в качестве средства для полного проявления метаболических процессов возделываемой культуры $[10,11]$.

Полученные за годы исследований данные показывают, что применяемый в опыте препарат NAGRO заметно усиливает ростовые и физиологические процессы, обеспечивает лучшее минеральное и воздушное питание растений в течение индивидуального развития растений кормового ячменя, в результате увеличивается урожайность (табл. 6).

Исследования показали, что применяемые факторы способствуют увеличению урожайности на 2,49 - 6,32 ц/га, наибольшую прибавку к контролю обеспечивает применение NAGRO на фоне с комплексными серосодержащими минеральными удобрениями, что составляет 21,5\%

Величина формируемого урожая кормового ячменя и других культур складывается из основных
Таблица 5

Влияние препарата NAGRO и минеральных удобрений на чистую продуктивность фотосинтеза растений ячменя, г/м2 в сутки, 20152017 гг.

\begin{tabular}{|c|c|c|c|c|}
\hline Вариант & $\begin{array}{c}\text { Всходы } \\
- \\
\text { куще- } \\
\text { ние }\end{array}$ & $\begin{array}{c}\text { Кущение } \\
- \\
\text { выход в } \\
\text { трубку }\end{array}$ & $\begin{array}{c}\text { Выход в } \\
\text { трубку - } \\
\text { колоше- } \\
\text { ние }\end{array}$ & $\begin{array}{c}\text { Колошение- } \\
\text { молочно- } \\
\text { восковая } \\
\text { спелость }\end{array}$ \\
\hline \multicolumn{5}{|c|}{2015 год } \\
\hline Контроль & 3,20 & 8,61 & 8,75 & 2,93 \\
\hline NAGRO & 3,23 & 8,87 & 8,96 & 3,47 \\
\hline $\begin{array}{c}\text { Контроль + } \\
\text { NPK }\end{array}$ & 3,20 & 9,42 & 9,57 & 3,50 \\
\hline $\begin{array}{l}\text { NAGRO + } \\
\text { NPK }\end{array}$ & 3,37 & 9,24 & 9,66 & 3,39 \\
\hline $\begin{array}{c}\text { Контроль } \\
+ \text { NPKS }\end{array}$ & 3,25 & 9,44 & 9,65 & 3,40 \\
\hline $\begin{array}{c}\text { NAGRO + } \\
\text { NPKS }\end{array}$ & 3,24 & 9,50 & 9,43 & 3,23 \\
\hline \multicolumn{5}{|c|}{ 2016год } \\
\hline Контроль & 3,52 & 9,10 & 12,10 & 4,40 \\
\hline NAGRO & 3,59 & 9,13 & 12,80 & 4,23 \\
\hline $\begin{array}{c}\text { Контроль + } \\
\text { NPK }\end{array}$ & 3,72 & 9,16 & 12,87 & 4,44 \\
\hline $\begin{array}{c}\text { NAGRO + } \\
\text { NPK }\end{array}$ & 3,73 & 9,29 & 12,94 & 4,20 \\
\hline $\begin{array}{c}\text { Контроль } \\
\text { +NPKS }\end{array}$ & 3,80 & 9,51 & 13,08 & 4,25 \\
\hline $\begin{array}{c}\text { NAGRO + } \\
\text { NPKS }\end{array}$ & 3,76 & 9,48 & 12,95 & 4,37 \\
\hline \multicolumn{5}{|c|}{2017 год } \\
\hline Контроль & 3,25 & 8,79 & 11,65 & 3,86 \\
\hline NAGRO & 3,43 & 8,77 & 13,23 & 4,29 \\
\hline $\begin{array}{c}\text { Контроль + } \\
\text { NPK }\end{array}$ & 3,64 & 9,20 & 13,91 & 4,40 \\
\hline $\begin{array}{l}\text { NAGRO + } \\
\text { NPK }\end{array}$ & 3,63 & 9,15 & 13,95 & 4,44 \\
\hline $\begin{array}{c}\text { Контроль } \\
+ \text { NPKS }\end{array}$ & 3,65 & 9,10 & 13,99 & 4,45 \\
\hline $\begin{array}{l}\text { NAGRO + } \\
\text { NPKS }\end{array}$ & 3,61 & 9,11 & 13,82 & 4,23 \\
\hline
\end{tabular}

элементов структуры урожайности: высота растений, длина колоса и масса 1000 семян. Структурноморфологический анализ урожайности кормового ячменя по сноповому материалу показывает, что регулятор роста NAGRO оказывают заметное положительное влияние на все элементы структуры.

Таким образом, применение NAGRO и внесение минеральных удобрений оказывают положительное влияние на продукционные процессы, что в конечном итоге способствует повышению уровня урожайности кормового ячменя.

Качество зерна определяется совокупностью действия внутренних факторов - естествен- 
ных особенностей растений и внешних факторов - состава почвы, климатических условий и совокупности агротехнических мероприятий [11, 12, 13].

Натура, или объемная масса зерна, включается по существующему Государственному стандарту (ГОСТ Р 53900-2010) в число обязательных показателей при оценке кормового ячменя.

Исследования показали, что самая высокая натура зерна наблюдается в варианте NAGRO на фоне минеральных серосодержащих удобрений, что выше контроля на 5,9 \% в 2015 году, в 2016 году- на 2,4 \%, в 2017 году -на 2,3\%. В среднем за годы исследований прибавка от используемых факторов составила 7,0 - 24,0 г\л, в зависимости от варианта (табл. 7).

Ввиду того, что натура не может дать всестороннего представления о физической добротно-

Таблица 6

Влияние препарата NAGRO и минеральных удобрений на урожайность кормового ячменя сорта Нутанс 553 (2015-2017гг.), ц/га

\begin{tabular}{|c|c|c|c|c|c|c|}
\hline \multirow{2}{*}{ Вариант } & \multicolumn{5}{|c|}{ Урожайность } & \multicolumn{2}{|c|}{ Прибавка } \\
\cline { 2 - 7 } & 2015 г. & 2016 г. & 2017 г. & $\begin{array}{c}\text { Сред- } \\
\text { нее }\end{array}$ & ц/га & $\%$ \\
\hline Контроль & 28,57 & 29,44 & 30,23 & 29,41 & - & - \\
\hline NAGRO & 32,30 & 32,97 & 31,77 & 32,35 & 2,94 & 10,0 \\
\hline $\begin{array}{c}\text { Контроль }+ \\
\text { NPK }\end{array}$ & 32,98 & 31,70 & 31,01 & 31,90 & 2,49 & 8,5 \\
\hline $\begin{array}{c}\text { NAGRO + } \\
\text { NPK }\end{array}$ & 33,65 & 34,05 & 32,90 & 33,53 & 4,12 & 14,0 \\
\hline $\begin{array}{c}\text { Контроль }+ \\
\text { NPKS }\end{array}$ & 34,65 & 32,00 & 34,53 & 33,73 & 4,32 & 14,7 \\
\hline $\begin{array}{c}\text { NAGRO + } \\
\text { NPKS }\end{array}$ & 35,79 & 36,04 & 35,36 & 35,73 & 6,32 & 21,5 \\
\hline $\begin{array}{c}\text { HCP } \\
05\end{array}$ & 0,58 & 0,48 & 0,46 & & & \\
\hline
\end{tabular}

\section{Таблица 7}

Натура и масса 1000 зерен ячменя, (2015-2017 гг.)

\begin{tabular}{|c|c|c|c|c|c|c|c|c|}
\hline \multirow{2}{*}{ Вариант } & \multicolumn{3}{|c|}{ Натура ячменя, г/л } & \multicolumn{3}{c|}{ Масса 1000 зерен, г } \\
\cline { 2 - 9 } & $2015 г$. & $2016 г$. & $2017 г$. & $\begin{array}{c}\text { Сред- } \\
\text { нее }\end{array}$ & 2015г. & 2016г. & 2017г. & $\begin{array}{c}\text { Сред- } \\
\text { нее }\end{array}$ \\
\hline Контроль & 660 & 685 & 682 & 675,7 & 48,7 & 49,2 & 48,5 & 48,8 \\
\hline NAGRO & 667 & 690 & 686 & 681,0 & 49,0 & 50,1 & 49,1 & 49,4 \\
\hline $\begin{array}{c}\text { Контроль + } \\
\text { NPK }\end{array}$ & 666 & 695 & 692 & 684,3 & 48,9 & 49,8 & 49,8 & 49,5 \\
\hline NAGRO + NPK & 672 & 680 & 696 & 682,7 & 49,6 & 49,6 & 50,0 & 49,7 \\
\hline $\begin{array}{c}\text { Контроль + } \\
\text { NPKS }\end{array}$ & 698 & 700 & 695 & 697,7 & 49,7 & 50,7 & 50,0 & 50,1 \\
\hline $\begin{array}{c}\text { NAGRO + } \\
\text { NPKS }\end{array}$ & 699 & 702 & 698 & 699,7 & 49,8 & 50,9 & 50,1 & 50,3 \\
\hline HCP & 4,2 & 1,9 & 3,7 & & 0,19 & 0,33 & 0,85 & \\
\hline
\end{tabular}

сти исследуемого зерна, в лабораторной практике определяют еще вес 1000 зерен. Этот показатель рассматривается как дополнительный к объемному весу.

Показатель массы 1000 зерен ячменя во все годы исследований был наибольшим в варианте NAGRO на фоне минеральных серосодержащих удобрений. Прибавка составила 2,3 - 4,1 \% (табл. 7).

Пленчатость зерна - это отношение количества оболочек к общему количеству необрушенного зерна, выраженное в процентах. Пленчатость у зерна зависит от ряда факторов: сортовых особенностей, климатических условий, района выращивания. Пленчатость является одним из показателей пивоваренных качеств ячменя, но и для кормовых ячменей этот показатель играет немаловажную роль, так как именно оболочки богаты минералами и витаминами, что сказывается на кормовой ценности комбикормов, производимых из кормовых ячменей.

Результаты исследований показывают, что пленчатость зерна ячменя изменяется в зависимости от варианта. Минимальный процент пленчатости наблюдается в 2015 -2016 годах в варианте NAGRO на фоне серосодержащих минеральных удобрений, что составляет $10,4 \%$ (табл. 8). В 2017 году показатель пленчатости был выше, что можно объяснить большим количеством осадков в период вегетации.

Одним из основных показателей качества зерна кормового ячменя является содержание белка. Количество и качество белка в растении зависит от многих факторов, и, как показали исследования, большое значение имеют погодные условия вегетационного периода, особенно в фазу налива зерна.

Проведенные исследования показывают, что в среднем за годы исследований под влиянием изучаемых факторов содержание белка в зерне ячменя увеличивается на 0,07 -

1,20\% в зависимости от варианта (табл. 9). Наибольшее содержание белка получено в 2016 году в варианте NAGRO на фоне минеральных серосодержащих удобрений. Независимо от погодных условий под влиянием препарата NAGRO на всех фонах плодородия во все годы исследований происходит более интенсивное накопление белка в зерне опытной культуры.

Белок в ячмене содержит все необходимые аминокислоты, включая особо дефицитные и наиболее ценные (лизин и треонин). Зерно ячменя широко применяют в качестве высо- 
Влияние препарата NAGRO и минеральных удобрений на пленчатость ячменя, \% (20152017rг.)

\begin{tabular}{|c|c|c|c|c|}
\hline Вариант & 2015 г. & 2016 г. & 2017г. & Среднее \\
\hline Контроль & 11,2 & 11,4 & 11,7 & 11,4 \\
\hline NAGRO & 10,5 & 11,0 & 11,3 & 10,9 \\
\hline Контроль + NPK & 10,6 & 10,9 & 11,5 & 11,0 \\
\hline NAGRO + NPK & 10,8 & 11,0 & 11,3 & 11,0 \\
\hline Контроль + NPKS & 10,6 & 10,6 & 11,3 & 10,8 \\
\hline NAGRO + NPKS $^{\prime}$ & 10,4 & 10,4 & 11,3 & 10,7 \\
\hline HCP $_{05}$ & 0,17 & 0,15 & 0,14 & \\
\hline
\end{tabular}

Влияние препарата NAGRO и минеральных удобрений на содержание белка в зерне ячменя, \% (2015-2017гг.)

\begin{tabular}{|c|c|c|c|c|}
\hline \multirow{2}{*}{ Вариант } & \multicolumn{4}{|c|}{ Содержание белка } \\
\cline { 2 - 5 } & 2015 г. & 2016 г. & 2017 г. & Среднее \\
\hline Контроль & 9,3 & 9,5 & 9,2 & 9,33 \\
\hline NAGRO & 9,4 & 9,4 & 9,3 & 9,40 \\
\hline Контроль + NPK & 9,8 & 10,8 & 10,5 & 10,40 \\
\hline NAGRO + NPK & 9,7 & 10,5 & 10,2 & 10,10 \\
\hline Контроль + NPKS & 9,1 & 10,5 & 10,4 & 10,00 \\
\hline NAGRO + NPKS & 10,5 & 10,9 & 10,2 & 10,53 \\
\hline
\end{tabular}

Таблица 10

Влияние препарата NAGRO и минеральных удобрений на аминокислотный состав зерна ячменя, мг/г (среднее за 2015-2017 гг.)

\begin{tabular}{|c|c|c|c|c|c|c|c|c|c|}
\hline Вариант & Валин & Лейцин & $\begin{array}{c}\text { Изолей- } \\
\text { цин }\end{array}$ & Треонин & Метионин & $\begin{array}{c}\text { Гистидин } \\
\text { Лизин }\end{array} \begin{array}{c}\text { Фенилала- } \\
\text { нин }\end{array}$ & $\begin{array}{c}\Sigma \text { амино- } \\
\text { кислот }\end{array}$ \\
\hline Контроль & 4,68 & 7,35 & 2,63 & 3,91 & 0,97 & 3,22 & 3,81 & 4,28 & 30,87 \\
\hline NAGRO & 4,70 & 7,40 & 2,71 & 3,91 & 0,97 & 3,30 & 3,80 & 4,30 & 31,09 \\
\hline Контроль + NPK & 4,85 & 7,61 & 2,78 & 3,98 & 1,07 & 3,42 & 4,02 & 4,48 & 32,21 \\
\hline NAGRO + NPKS & 4,69 & 7,60 & 2,79 & 3,97 & 1,10 & 3,40 & 3,90 & 4,47 & 31,92 \\
\hline Контроль + NPKS & 5,25 & 8,16 & 3,10 & 4,25 & 1,13 & 3,68 & 4,18 & 4,75 & 34,51 \\
\hline NAGRO + NPKS & 5,20 & 8,00 & 3,00 & 4,00 & 1,00 & 3,60 & 4,10 & 4,70 & 33,60 \\
\hline
\end{tabular}

концентрированного корма. Удельный вес ячменя в составе комбикорма достигает до 50 \% и выше. Результаты исследований показывают, что суммарное количество аминокислот увеличивалось при использовании в технологии препарата NAGRO как на естественном фоне, так и на фоне минеральных удобрений, что связано с усилением азотного и углеводного метаболизмов. Прибавка к контролю составляет 0,22 - 3,64 мг ґг в зависимости от варианта. Данная тенденция наблюдается также и при анализе накопления отдельных аминокислот в зерне кормового ячменя (табл.10). Важно также учитывать сбалансированность незаменимых аминокислот в продукции. Слишком большой избыток одной из них может увеличить потребность в другой лимитирующей аминокислоте.

Возможно также явление антагонизма, когда избыток какой-то одной аминокислоты снижает использование другой с аналогичной структурой. В связи с этим определяется аминокислотный скор, который наиболее полно характеризует биологическую полноценность зерна. В качестве идеального белка применяли аминокислотную шкалу ФАО/ВОЗ.

В наших опытах лимитирующей аминокислотой является метионин. Под действием используемых факторов аминокислотный скор отдельных аминокислот повышается по отношению к контролю до 2,1\%.

\section{Выводы}

Итак, наши исследования подтверждают целесообразность использования регуляторов роста и минеральных удобрений в технологии возделывания кормового ячменя. Они способствуют улучшению метаболизма и энергетического обмена в растительном организме, тем самым создаются предпосылки для получения зерна высокого качества и увеличения уровня урожайности.

\section{Библиографический список}

1. Гайсин, И. А. Эффективность некорневой подкормки хелатным микроудобрением в сочетании с азотом в технологии возделывания яровой пшеницы на серых лесных почвах республики Татарстан / И. А. Гайсин, М. Г. Муртазин, С. Г. Муртазина // Зерновое хозяйство. - 2014. - № 2. - С.1-7.

2. Гайсин, И. А. Хелатные микроудобрения: практика применения и механизмы действия / И. А. Гайсин, В. М. Пахомова. - Йошкар-Ола : Стринг, 2014. -343 c.

3. Гущина, В. А. Биопрепараты и регуляторы роста в ресурсосберегающем земледелии / В. А. Гущина, А. А. Володькин. - Пенза : Пензенская государственная сельскохозяйственная академия, 2016. -206 c.

4. Еряшев, А. П. Влияние средств защиты растений и препарата «Альбит» на урожайность и качество зерна гороха / А. П. Еряшев, А. Г. Катаев, П. 
А. Катаев // Кормопроизводство. - 2014. - № 8. - С. $18-21$.

5. Электронный ресурс: Режим доступа http://нагро.рф/

6. Ивановский, Д. И. Физиология растений / Д. И. Ивановский. - Москва : Либроком, 2012. - 554 с.

7. Isaichev, V. A. Influence of growth regulators and mineral fertilizers on water regime and yielding capacity of barley plants/V. A. Isaichev, N. N. Andreev, K. A. Vinogradova // Research Journal of Pharmaceutical, Biological and Chemical Sciences. - 2018. - Vol. 9, № 2. - P. 1197-1202.

8. Боронтов, О. К. Формирование ассимиляционного аппарата при различных системах обработки почвы и удобрений / О. К. Боронтов // Сахарная свекла. - 2010. - № 6. - С. 15 - 17.

9. Мамонов, С. Н. Влияние удобрений на фотосинтетическую и зерновую продуктивность пшеницы / С. Н. Мамонов, В. Т. Синеговская // Земледелие. - 2012. - № 3. - С.40-41.

10. Жданов, В. М. Урожайность яровой мяг- кой пшеницы в Оренбургском Предуралье / В. М. Жданов, В. Ю. Скороходов, Ю. В. Кафтан // Известия Оренбургского государственного аграрного университета. - 2015. - № 1(51). - С. 24-26.

11. Урожайность и качество зерна озимой пшеницы в зависимости от технологии возделывания в полевом опыте центра точного земледелия / С. В. Железова, И. Ф. Шамбинго, А. В. Мельников, Е. В. Березовский // Вестник Алтайского государственного аграрного университета. - 2014. - № 10(120). - C.10-14.

12. Сорока, Т. А. Влияние регуляторов роста и микроэлементов на урожайность и качество зерна озимой пшеницы / Т. А. Сорока // Известия ОГАУ. 2012. - № 1-1. - C. 42-44.

13. Isaichev, V. A. Influence of macro and microelements on protein producing capacity in feed barley grain / V. A. Isaichev, V. I. Kostin, N. N. Andreev // Research Journal of Pharmaceutical, Biological and Chemical Sciences. - 2018. - Vol. 9, № 3. - P. 1473 1477.

\title{
INFLUENCE OF MINERAL FERTILIZERS AND NAGRO PRODUCT ON FEED BARLEY PRODUCTIVITY
}

\author{
Isaychev V.A., Andreev N.N., Kostin V.I. \\ FSBEI HE Ulyanovsk State Agrarian University \\ 432017, Ulyanovsk, Novyi Venets boulevard, 1; tel .: 8 (8422) 55-95-16 \\ e-mail: andreev919@yandex.ru
}

Key words: feed barley, liquid fertilizer mixtures, productivity, grain quality.

The aim of the study was to study the effectiveness of complex macro-fertilizers and NAGRO product, as well as their combinations in cultivation of feed barley in the forest-steppe of the Middle Volga. The applied factors positively affect water balance of feed barley plants. The greatest increase is provided by the use of NAGRO in combination with sulfur-containing mineral fertilizers. This parametre increases by $0.4-4.8 \%$ (2 hours), 0.7 - $4.4 \%$ (4 hours), $0.5-3.6 \%$ (6 hours). The germination energy in case of seed treatment with the test product increased by $0.5-1.6 \%$, in relation to the control. The application of NAGRO product had a positive effect on laboratory germination, which increases by an average of $0.4-2.3 \%$. Under the effect of the studied product, an increase of growth force occurs due to an increase of the length of germinal roots and seedlings. The greatest increase of dry matter in the test variants was observed in the phase of milk-wax ripeness. The applied factors contribute to an increase in productivity by $2.49-6.32 \mathrm{dt} / \mathrm{ha}$, the highest increase to control is provided by application of NAGRO in combination with complex sulfur-containing mineral fertilizers, which amounts to $21.5 \%$. The growth regulator NAGRO has a noticeable effect on all elements of the harvest structure. The greatest grain-unit is observed if NAGRO is used in combination with sulfur-containing mineral fertilizers. The increase from the factors used was $7.0-24.0 \mathrm{~g} / \mathrm{L}$, depending on the variant. Protein content in barley grain increases from 0.07 to $1.20 \%$ under the influence of the studied factors. The total amount of amino acids increased when NAGRO product was used, both against a natural background and against a background of mineral fertilizers. The increase in comparison to the control is $0.22-3.64 \mathrm{mg} / \mathrm{g}$.

\section{Bibliography}

1. Gaisin, I. A. The effectiveness of foliar feeding with chelated microfertilizer in combination with nitrogen in the technology of spring wheat cultivation on the gray forest soils of the Republic of Tatarstan / I. A. Gaisin, M. G. Murtazin, S. G. Murtazina // Grain farming . - 2014. - No. 2. - P.1-7.

2. Gaisin, I. A. Chelated microfertilizers: application practice and effect mechanisms /I. A. Gaisin, V. M. Pakhomova. - Yoshkar-Ola: String, 2014 .- 343 p.

3. Gushchina, V. A. Biological products and growth regulators in resource-saving agriculture / V. A. Gushchina, A. A. Volodkin. - Penza: Penza State Agricultural Academy, 2016. - 206 p.

4. Eryashev, A. P. Influence of plant protection products and the product "Albit" on productivity and quality of pea grain / A. P. Eryashev, A. G. Kataev, P. A. Kataev // Feed production. - 2014. - No. 8. - P. 18 - 21.

5. Electronic resource: Access mode - - http://Hazpo.pp/

6. Ivanovsky, D.I. Plant physiology / D.I. Ivanovsky. - Moscow: Librocom, 2012 .- 554 p.

7. Isaichev, V. A. Influence of growth regulators and mineral fertilizers on water regime and yielding capacity of barley plants / V. A. Isaichev, N. N. Andreev, K. A. Vinogradova // Research Journal of Pharmaceutical, Biological and Chemical Sciences. - 2018. - Vol. 9, № 2. - P. 1197-1202.

8. Borontov, O. K. Formation of the assimilation apparatus in various systems of tillage and fertilizers / O. K. Borontov//Sugar beetroot. - 2010. - No. 6. - P. $15-17$.

9. Mamonov, S. N. Influence of fertilizers on photosynthetic and grain productivity of wheat / S. N. Mamonov, V. T. Sinegovskaya // Agriculture. - 2012. No. 3. - P. 40-41.

10. Zhdanov, V. M. Yield of spring soft wheat in Orenburg Cis-Ural region / V. M. Zhdanov, V. Yu. Skorokhodov, Yu. V. Kaftan // Vestnik of Orenburg State Agrarian University. - 2015. - No. 1 (51). - P. 24-26.

11. Productivity and grain quality of winter wheat, depending on cultivation technology in the field experiment of the center of precision farming / S. $V$. Zhelezova, I. F. Shambingo, A. V. Melnikov, E. V. Berezovsky // Vestnik of Altai State Agrarian University . - 2014. - No. 10 (120). - P.10-14.

12. Soroka, T. A. Influence of growth regulators and microelements on winter wheat grain yield and quality/T. A. Soroka //Izvestya of OSAU. - 2012. - No. 1-1. - P. 42-44.

13. Isaichev, V. A. Influence of macro and microelements on protein producing capacity in feed barley grain / V. A. Isaichev, V. I. Kostin, N. N. Andreev // Research Journal of Pharmaceutical, Biological and Chemical Sciences. -2018. - Vol. 9, № 3. - P. 1473 - 1477. 